\title{
Effects of Native and Denatured Whey Proteins on Plasminogen Activator Activity
}

\author{
K. M. Rippel, S. S. Nielsen, and K. D. Hayes \\ Department of Food Science, Purdue University, \\ West Lafayette, IN 47907
}

\begin{abstract}
The plasmin system native to bovine milk consists of the caseinolytic serine proteinase plasmin; its inactive zymogen, plasminogen; plasminogen activators; and inhibitors. Evidence in the literature indicates that whey proteins may inhibit plasmin activity, but there is very little mention of their effect on plasminogen activators. The objective of this research was to determine the effect of both unheated and heat-denatured $\beta$-lactoglobulin ( $\beta$-LG), $\alpha$-lactalbumin ( $\alpha$-LA), and BSA on plasminogen activators.

Plasminogen activator activity was significantly stimulated by non-heat treated and denatured $\alpha$-LA as well as by denatured $\beta$-LG. The stimulation effect by these whey proteins was kinetically characterized, which showed that all 3 significantly increased the rate of plasminogen activation. The stimulation effect was shown to be independent of any effect of the whey proteins on plasmin activity by testing 2 different substrates, D-Val-Leu-Lys $p$-nitroanilide (S-2251) and Spectrozyme PL (Spec PL), in a plasmin assay. Results using S-2251 confirmed the inhibitory effect of whey proteins on plasmin observed by several researchers. However, use of SpecPL did not suggest inhibition. Ligand binding studies showed this discrepancy to be due to significant interaction between S-2251 and the whey proteins. Overall, this study indicates that whey protein incorporation into cheese may not hinder plasmin activity and may stimulate plasminogen activation. Furthermore, the results indicate the need for careful consideration of the type of synthetic substrate chosen for model work involving whey proteins and the plasmin system. (Key words: plasminogen activator, whey protein, plasmin)
\end{abstract}

Abbreviation key: d $\alpha$-LA $=$ denatured $\alpha$-LA, $\mathbf{d} \beta$ $\mathbf{L G}=$ denatured $\beta$-LG, $\mathbf{K}_{\mathbf{P G}}=$ Michaelis-Menten constant for plasminogen activator, $\mathbf{k}_{\mathbf{P G}}=$ rate constant

Received February 2, 2004.

Accepted April 7, 2004.

Corresponding author: K. D. Hayes; e-mail: hayesk@foodsci. purdue.edu. for plasminogen activation, $\mathbf{P A}=\mathrm{PG}$ activator, $\mathbf{P G}=$ plasminogen, $\mathbf{P L}=$ plasmin, $\mathbf{S - 2 2 5 1}=\mathrm{D}-$ Val-Leu-Lys $p$-nitroanilide, $\mathbf{S p e c P L}=$ Spectrozyme PL, $\mathbf{u P A}=$ urokinase-type PA.

\section{INTRODUCTION}

Plasmin (PL; EC 3.4.21.7), a serine proteinase, is the major native proteinase found in milk. Its proteolytic action, which is similar to that of trypsin, can greatly influence the quality of many dairy products. Its zymogen, plasminogen $(\mathbf{P G})$, is present in milk at concentrations 2 to 100 times that of PL (Bastian and Brown, 1996). Plasminogen can be activated to PL by PG activators (PA), of which there are 2 main types present in milk: urokinase-type (uPA) and tissue-type. Further descriptions of the PL system's characteristics and activity are available in review articles (Grufferty and Fox, 1988; Bastian and Brown, 1996).

The literature contains a wealth of information on the positive and negative aspects of incorporating whey proteins into milk used for cheese manufacture. In a review, Singh and Waungana (2001) summarized some of the effects of the interactions between whey proteins and components of milk (casein micelles, minerals, fat globules, etc.). On the positive side, whey proteins incorporated into cheese milk can increase yield. On the negative side, they can interfere with the rennetting process and adversely affect the final texture and flavor of the cheese.

The effect of whey proteins on PL has been explored because of their incorporation into cheese curd. Bastian et al. (1993) reported inhibition of PL by $\beta$-LG using the synthetic substrate D-Val-Leu-Lys $p$-nitroanilide (S-2251) and showed that native $\beta$-LG was more inhibitory than was denatured $\beta$-LG $(\mathbf{d} \beta-\mathbf{L G})$. Hayes et al. (2002) measured inhibition of PL activity by $\beta$-LG and $\mathrm{d} \beta$-LG based on urea-PAGE analysis of $\beta$-CN breakdown but reported stimulation of PL activity by $\beta$-LG and $\mathrm{d} \beta$-LG as high as 1.5-fold using a fluorometric substrate in an enzymatic assay. Hayes et al. (2002) performed their assays at $\mathrm{pH} 5.2$, whereas Bastian et al. (1993) ran their assays at $\mathrm{pH}$ 7.4. Like Bastian et al. (1993), Politis et al. (1993) also reported inhibition of 
PL activity by $\beta$-LG using S-2251 as the substrate, as well as noting a concentration-dependent inhibition. Both Hayes et al. (2002) and Politis et al. (1993) also investigated $\alpha$-LA and BSA. Hayes et al. (2002) reported inhibition of PL activity by both $\alpha$-LA and BSA based on urea-PAGE results, but observed stimulation as high as 2.5-fold in their enzymatic assays. Politis et al. (1993) found that both $\alpha$-LA and BSA inhibited PL activity. All of the studies used commercially purchased whey proteins, and none of them looked at the effect of whey proteins on PG or PA.

The literature contains one abstract (Politis et al., 1995) on the effect of whey proteins on PA. This abstract compared the abilities of casein and the major whey proteins to accelerate the activation of PG to PL. The study indicated that BSA, $\beta$-LG, and $\alpha$-LA caused $3-$ to 5 -fold acceleration of PG activation. Politis et al. (1995) noted an equal acceleration effect among the whey proteins, but that this acceleration was less than that of $\alpha$-CN.

Because of the lack of complete knowledge of the interactions between whey proteins and PA, the objective of this study was to determine the effects, if any, of $\beta$-LG, $\alpha-\mathrm{LA}$, and BSA, in their native and denatured forms, on PA. The chromogenic substrate Spectrozyme PL (SpecPL) was used, as well as S-2251, in PL assays to account for any effect of whey proteins on PL, which was produced in the 2-step assay used to observe whey protein effects on PA.

\section{MATERIALS AND METHODS}

$\alpha$-Lactalbumin (product \#L-5385), $\beta$-LG (product \#L3908), BSA (product \#B-6917), bovine PL (product \#P7911, no longer available), and S-2251 (product \#V0882) were all purchased from Sigma Chemical Co. (St. Louis, MO). Bovine PG (product \#416), human uPA (product \#124), and SpecPL; product \#251L) were all purchased from American Diagnostica (Greenwich, CT). Bovine PL also was purchased from Roche Diagnostics (product \#602 370, Indianapolis, IN). Unless otherwise noted, Roche PL was used in all assays because of the loss of availability of Sigma PL part-way through the study. All reagents described previously were diluted to appropriate concentrations in modified Tris buffer ( $0.05 M$ Tris, $0.1 M \mathrm{NaCl}, 0.01 \%$ Tween 80 ; $\mathrm{pH}$ 7.6).

\section{Whey Protein Dilution Protocol}

Whey proteins were diluted to achieve final concentrations in assays that would mimic those naturally found in milk. Based on the milk whey protein concentrations given in Bylund (1995), the following concen- trations were used: $\alpha$-LA, $1.24 \mathrm{mg} / \mathrm{mL} ; \beta-\mathrm{LG}, 3.31 \mathrm{mg} /$ $\mathrm{mL}$; and BSA, $0.41 \mathrm{mg} / \mathrm{mL}$. In preliminary studies (data not shown), 3 concentrations of unheated and heat denatured $\alpha$-LA (d $\alpha$-LA) $(0.2,0.55$, and $1.24 \mathrm{mg} / \mathrm{mL})$ and $\mathrm{d} \beta$-LG $(0.5,1.45$, and $3.31 \mathrm{mg} / \mathrm{mL})$ were assayed to observe the concentration effects of these proteins. Unheated $\beta$-LG was not assayed for a concentration effect because it had no effect in preliminary studies (data not shown $)$. The concentration of each protein $(0.55 \mathrm{mg} /$ $\mathrm{mL}$ for unheated and $\mathrm{d} \alpha-\mathrm{LA}$ and $3.31 \mathrm{mg} / \mathrm{mL}$ for $\mathrm{d} \beta$ LG) that had the biggest effect was used in all further work, unless otherwise noted.

\section{Whey Protein Denaturation Protocol}

For studies involving denatured whey proteins, volumes appropriate for each assay were incubated in microcentrifuge tubes for $10 \mathrm{~min}$ at $100^{\circ} \mathrm{C}$. They were then cooled at $37^{\circ} \mathrm{C}$ for 5 min and assayed immediately following the cooling period. Any leftover denatured solution was discarded.

\section{Coupled Assay of PA Activity}

A 2-step reaction involving the activation of $P G$ to PL by uPA, coupled simultaneously with hydrolysis of SpecPL by the resulting PL, was used to assay PA activity. For the control reaction, $25 \mu \mathrm{L}$ of $3.2 \mathrm{~m} M$ SpecPL was reacted with $25 \mu \mathrm{L}$ of $1.5 \mathrm{IU} / \mathrm{mL} \mathrm{uPA}, 25 \mu \mathrm{L}$ of $0.032 \mathrm{mg} / \mathrm{mL} \mathrm{PG}$ and $25 \mu \mathrm{L}$ of modified Tris buffer. Reaction conditions were identical when whey proteins were added, except the volume of modified Tris buffer was replaced with an equal volume of whey protein solution. These reactions were carried out with appropriate blanks in 96-well microtiter plates that were incubated at $37^{\circ} \mathrm{C}$ for $60 \mathrm{~min}$. Plates were measured for absorbance at 405, 490, and $405-490 \mathrm{~nm}$ on an ELISA plate reader (Vmax Kinetic Microplate Reader; Molecular Devices Co., Menlo Park, CA). The 405- 490-nm measurement is a calculated value, whereby the plate reader repeats its measurements at both wavelengths and gives the absorbance value as the difference between the 2 . The absorbance measurement at $490 \mathrm{~nm}$ corrected for any turbidity in the sample.

\section{Kinetic Studies}

Based on results from the end point assays described previously, kinetic studies were performed on the coupled assay with and without the addition of unheated and heat denatured $0.55 \mathrm{mg} / \mathrm{mL} \alpha-\mathrm{LA}$ and $3.31 \mathrm{mg} / \mathrm{mL}$ $\mathrm{d} \beta$-LG. The following scheme describes the reactions that took place in this assay: 


$$
\begin{gathered}
\mathrm{PG}+\mathrm{PA} \stackrel{\mathrm{K}_{\mathrm{PG}}>\mathrm{PG}}{\longrightarrow \mathrm{PA} \stackrel{\mathrm{k}_{\mathrm{PG}}}{\longrightarrow} \mathrm{PA}+\mathrm{PL}} \\
\mathrm{PL}+\text { Substrate } \longleftrightarrow \mathrm{PL} \\
- \text { Substrate } \longrightarrow \mathrm{PL}+\mathrm{pNA}+\text { tripeptide }
\end{gathered}
$$

where pNA is the p-nitroanilide group released from the chromogenic substrate, $\mathbf{K}_{\mathbf{P G}}$ is the Michaelis-Menten constant for PA, and $\mathbf{k}_{\mathbf{P G}}$ is the rate constant for $\mathrm{PG}$ activation. The model described by Nishino et al. (2000), with the following modifications, was used to analyze the coupled reaction and calculate the desired kinetic parameters from the data.

- SpecPL was used as the synthetic substrate specific for PL, rather than S-2251.

- All reagents were diluted in modified Tris buffer as described previously.

- Sigma-brand PL (2 mU/mL) was characterized by reacting it with varying volumes of $1.6 \mathrm{~m} M$ SpecPL.

This characterization was done for 2 reasons: 1 ) to determine the saturating concentration of SpecPL in this reaction such that the reaction would be running under steady-state conditions in the coupled assay and 2) to determine the kinetic parameters of PL so that they could be used in the model of Nishino et al. (2000) to determine the kinetic parameters of the coupled reaction.

- For the control, human uPA (1.5 IU/mL) was characterized by reacting it with varying volumes of $0.032 \mathrm{mg} / \mathrm{mL}$ bovine PG and a constant volume of $3.2 \mathrm{~m} M$ SpecPL. For treatments, whey proteins were added (replacing an equal amount of buffer) to achieve $0.55 \mathrm{mg} / \mathrm{mL} \alpha$-LA or $3.31 \mathrm{mg} / \mathrm{mL} \mathrm{d} \beta-\mathrm{LG}$ in the total reaction volume.

- All kinetic reactions (total volume, $700 \mu \mathrm{L}$ ) were carried out in a spectrophotometer (Beckman DU 640; Beckman Institute, Inc., Fullerton, CA) equipped with a temperature-controlled cuvette holder prewarmed to and maintained at $37^{\circ} \mathrm{C}$. Reactions were run for $1 \mathrm{~h}$ and repeated 3 times. In each case, absorbance measurements were taken at 405 and $490 \mathrm{~nm}$ every $4 \mathrm{~min}$ throughout the 60 min reaction period.

The apparent overall PG activation rate was determined by first converting absorbance values to p-nitroanilide concentration using the molar absorptivity given in Wohl et al. (1980) and then plotting the concentration of p-nitroanilide released vs. time-squared. The rate of $P G$ activation was calculated using apparent overall PG activation rate data, and the rate of SpecPL hydrolysis by PL, as detailed in Nishino et al. (2000). Lineweaver-Burk plots were constructed by plotting the reciprocal of values for the rate of $P G$ activation against the reciprocal of the $\mathrm{PG}$ concentrations. The desired kinetic parameters, $\mathrm{K}_{\mathrm{PG}}, \mathrm{k}_{\mathrm{PG}}$, and $\mathrm{k}_{\mathrm{PG}} / \mathrm{K}_{\mathrm{PG}}$, could be calculated from the Lineweaver-Burk plots. A more detailed description of the method can be found in Rippel (2003).

\section{PL Activity Assay}

Because PL was produced in the PA assay described previously, the effects of the whey proteins could have been on PL, and not on uPA. To investigate and account for this possibility, PL activity in the presence of whey proteins was investigated. The PL activity using SpecPL as the substrate was determined by reacting $75 \mu \mathrm{L}$ of $1.6 \mathrm{~m} M$ SpecPL with $25 \mu \mathrm{L}$ of $6.4 \mathrm{mU} / \mathrm{mL}$ PL. To observe PL activity in the presence of a whey protein, $37.5 \mu \mathrm{L}$ of $3.2 \mathrm{mM}$ SpecPL was reacted with $12.5 \mu \mathrm{L}$ of $12.8 \mathrm{mU} / \mathrm{mL} \mathrm{PL}$ and $12.5 \mu \mathrm{L}$ of the appropriate whey protein solution of interest. Modified Tris buffer was added to achieve a total volume of $100 \mu \mathrm{L}$.

The PL activity assayed using S-2251 as the substrate was observed by reacting $69.1 \mu \mathrm{L}$ of $1.0 \mathrm{mM}$ S2251 with $5.9 \mu \mathrm{L}$ of $100 \mathrm{mU} / \mathrm{mL}$ PL and $25 \mu \mathrm{L}$ modified Tris buffer. The volume of modified Tris buffer was replaced with the whey protein solution of interest when its effect on PL activity was observed. Whey proteins were added to achieve the same concentrations as in the PL assays using SpecPL. These reaction conditions were chosen to approximate those used by Bastian et al. (1993). Reactions with both substrates were carried out as described for the PA assay.

\section{Equilibrium Dialysis Method to Study Ligand Binding}

Because an inhibitory effect of $\beta$-LG and $\alpha$-LA was observed in the S-2251 PL assay, but not in the SpecPL PL assay, a possible interaction between the whey proteins and S-2251 was investigated. This was done using equilibrium dialysis, a classic physical chemistry method to study ligand binding to macromolecules. A detailed description of the theory behind this method is available in Chang (2000). Basically, the amount of unbound substrate that passed through dialysis tubing into the surrounding dialysate was measured for a control containing no whey protein and treatments containing $\alpha$-LA or $\beta$-LG.

For the equilibrium dialysis, the minimum volume required to externally cover the dialysis tubing was empirically determined to be $40 \mathrm{~mL}$. Assuming a 10- 
Table 1. Reagents and concentrations used for equilibrium dialysis.

\begin{tabular}{|c|c|c|c|c|c|}
\hline Tube & Sample & $\mathrm{DDW}^{1}(\mathrm{~mL})$ & $\begin{array}{l}8 \mathrm{~m} M \\
\mathrm{~S}-2251^{2}(\mathrm{~mL})\end{array}$ & $\begin{array}{l}13.24 \mathrm{mg} / \mathrm{mL} \\
\beta-\mathrm{LG}(\mathrm{mL})\end{array}$ & $\begin{array}{l}4.96 \mathrm{mg} / \mathrm{mL} \\
\alpha-\mathrm{LA}(\mathrm{mL})\end{array}$ \\
\hline 1 & Control & 3 & 1 & 0 & 0 \\
\hline 2 & $3.31 \mathrm{mg} / \mathrm{mL} \beta-\mathrm{LG}$ & 2 & 1 & 1 & 0 \\
\hline 3 & $9.93 \mathrm{mg} / \mathrm{mL} \beta-\mathrm{LG}$ & 0 & 1 & 3 & 0 \\
\hline 4 & $1.24 \mathrm{mg} / \mathrm{mL} \beta$-LA & 2 & 1 & 0 & 1 \\
\hline 5 & $3.72 \mathrm{mg} / \mathrm{mL} \beta$-LA & 0 & 1 & 0 & 3 \\
\hline
\end{tabular}

fold dilution from the inside of the tube to the outside, this minimum outside volume dictated an inside volume of $4 \mathrm{~mL}$. Five tubes were prepared using dialysis tubing with a molecular weight cut-off of 3500 (product \# 132724; Spectrum Laboratories, Rancho Dominguez, CA). This tubing would not allow permeation of the whey proteins. Table 1 lists the volumes and concentrations of reagents used to prepare the tubes. Tubes 2 and 4 contained the same concentrations of $\beta$-LG (3.31 $\mathrm{mg} / \mathrm{mL})$ and $\alpha$-LA $(1.24 \mathrm{mg} / \mathrm{mL})$, respectively, that were used in the PL assay previously described. Tubes 3 and 5 contained the maximum concentrations of $\beta$-LG (9.93 $\mathrm{mg} / \mathrm{mL})$ and $\alpha$-LA $(3.72 \mathrm{mg} / \mathrm{mL})$, respectively, that could be obtained inside the dialysis tubing without clogging the membrane. The prepared tubes were clamped and immersed in $40 \mathrm{~mL}$ of deionized distilled water in separate containers. Dialysis was performed for $4 \mathrm{~h}$ at room temperature $\left(22^{\circ} \mathrm{C}\right)$. Once dialysis was completed, a PL assay identical to the one described previously for the control reaction run with S-2251 was performed to determine the amount of substrate present in the dialysate.

\section{Statistical Analysis}

Data were analyzed by following ANOVA procedures to investigate differences between controls and treatments. Specifically, PROC GLM, Dunnett, and TukeyKramer multiple means comparison procedures were followed using the SAS System for Windows software, version 8.0, and a significance level of 0.05 (SAS, 2001).

\section{RESULTS AND DISCUSSION}

\section{Effect of Whey Proteins on PG Activation}

The corrected absorbance results for each of the reactions run with the addition of a whey protein are compared with a control in Figure 1 and provide visualization of the stimulatory effects of the whey proteins. The treatment of adding individual whey proteins to the coupled assay was significant $(P<0.0001)$. However, based on a Dunnett means comparison procedure, only the reactions containing $\alpha-\mathrm{LA}, \mathrm{d} \alpha-\mathrm{LA}$, and dBLG were significantly different from the control reaction $(P<$ $0.05)$. This trend of stimulation is consistent with the PG activation acceleration reported by Politis et al. (1995), although the magnitude of stimulation is different and equal acceleration effects among the whey proteins were not observed.

The results shown in Figure 1 provide no insight as to how $\alpha$-LA, d $\alpha$-LA, and $\mathrm{d} \beta$-LG affect PG activation. Kinetic characterization of their effects was therefore carried out to elucidate the nature of the stimulation. That is, kinetic results could be used to gain insight into the mechanism of stimulation and whether the whey proteins were affecting uPA itself or the PGuPA complex.

\section{Results of Kinetic Studies}

Table 2 summarizes the $\mathrm{K}_{\mathrm{PG}}, \mathrm{k}_{\mathrm{PG}}$, and $\mathrm{k}_{\mathrm{PG}} / \mathrm{K}_{\mathrm{PG}}$ values for the control and whey protein-containing coupled reactions that were calculated from the kinetic studies of the coupled reaction. The ratio of $k_{P G}$ to $K_{P G}$ is a measure of the enzyme's efficiency at catalyzing the

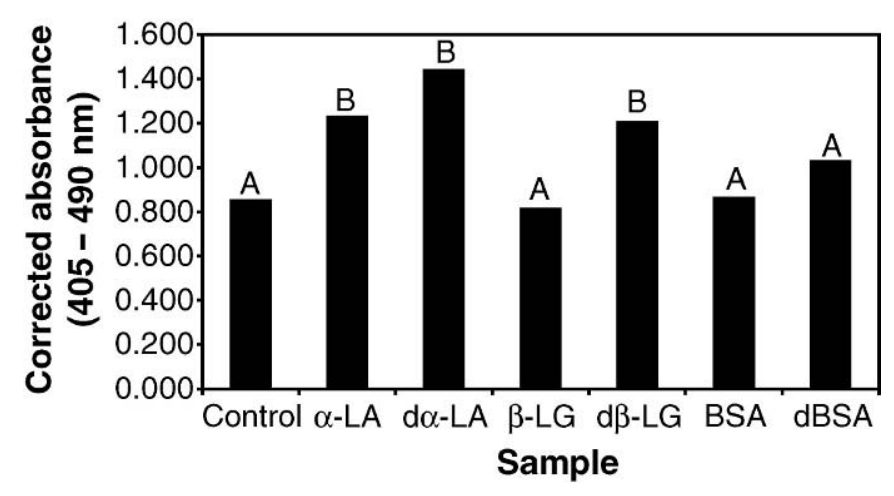

Figure 1. Average corrected absorbances showing the effect of adding whey proteins on the coupled assay monitoring plasminogen activation by human urokinase-type plasminogen activator. $\mathrm{d} \alpha$-LA $=$ denatured $\alpha$-LA, $\mathrm{d} \beta-\mathrm{LG}=$ denatured $\beta$-LG, and $\mathrm{dBSA}=$ denatured BSA. Means with the same letter are not significantly different from the control based on the Dunnett procedure. 
Table 2. Summary of kinetic parameters calculated from the kinetic studies performed on a control and whey protein-containing reactions of interest.

\begin{tabular}{|c|c|c|c|c|}
\hline Reaction & Parameter $^{1}$ & $\begin{array}{l}\text { Degrees of } \\
\text { freedom }\end{array}$ & $\begin{array}{l}\text { Mean } \\
\text { square }\end{array}$ & Significance \\
\hline \multicolumn{5}{|l|}{ Control } \\
\hline $\mathrm{K}_{\mathrm{PG}^{2}}{ }^{2}$ & $6.29 \times 10^{-5} \pm 1.62 \times 10^{-5}$ & & & \\
\hline $\mathrm{k}_{\mathrm{PG}}{ }^{3}$ & $0.41 \pm 0.134$ & & & \\
\hline $\mathrm{k}_{\mathrm{PG}} / \mathrm{K}_{\mathrm{PG}}{ }^{4}$ & $7.24 \times 10^{3} \pm 4.61 \times 10^{3}$ & & & \\
\hline \multicolumn{5}{|l|}{ With $\alpha$-LA } \\
\hline $\mathrm{K}_{\mathrm{PG}}$ & $1.74 \times 10^{-4} \pm 1.28 \times 10^{-5}$ & 1 & $1.8541814 \times 10^{-8}$ & $0.0007 *$ \\
\hline $\mathrm{k}_{\mathrm{PG}}$ & $2.90 \pm 0.179$ & 1 & 9.35001667 & $<0.0001^{*}$ \\
\hline $\mathrm{k}_{\mathrm{PG}} / \mathrm{K}_{\mathrm{PG}}$ & $1.67 \times 10^{4} \pm 4.24 \times 10^{2}$ & 1 & 133953750 & $0.0245^{*}$ \\
\hline \multicolumn{5}{|l|}{ With $\mathrm{d} \alpha-\mathrm{LA}^{5}$} \\
\hline $\mathrm{K}_{\mathrm{PG}}$ & $4.58 \times 10^{-5} \pm 2.42 \times 10^{-5}$ & 1 & $3.9511935 \times 10^{-8}$ & 0.4345 \\
\hline $\mathrm{k}_{\mathrm{PG}}$ & $1.17 \pm 0.404$ & 1 & 0.8664 & $0.0365^{*}$ \\
\hline $\mathrm{k}_{\mathrm{PG}} / \mathrm{K}_{\mathrm{PG}}$ & $2.87 \times 10^{4} \pm 9.19 \times 10^{3}$ & 1 & 690153750 & $0.0225^{*}$ \\
\hline \multicolumn{5}{|l|}{ With $d \beta-\mathrm{LG}^{6}$} \\
\hline $\mathrm{K}_{\mathrm{PG}}$ & $2.61 \times 10^{-5} \pm 8.36 \times 10^{-6}$ & 1 & $2.03136 \times 10^{-9}$ & $0.0250 *$ \\
\hline $\mathrm{k}_{\mathrm{PG}}$ & $0.93 \pm 0.00$ & 1 & 0.41081667 & $0.0025^{*}$ \\
\hline $\mathrm{k}_{\mathrm{PG}} / \mathrm{K}_{\mathrm{PG}}$ & $3.82 \times 10^{4} \pm 1.20 \times 10^{4}$ & 1 & 1430670417 & $0.0141^{*}$ \\
\hline
\end{tabular}

\footnotetext{
${ }^{1}$ Average \pm standard deviation, where $\mathrm{n}=3$ in all cases.

${ }^{2}$ Michaelis-Menten constant for plasminogen activation.

${ }^{3}$ Rate constant for plasminogen activation.

${ }^{4}$ Catalytic efficiency of urokinase-type plasminogen activator.

${ }^{5} \mathrm{~d} \alpha$-LA $=$ Denatured $\alpha$-LA.

${ }^{6} \mathrm{~d} \beta$-LG $=$ Denatured $\beta$-LG.

$* P<0.05$, based on the Dunnett means comparison procedure.
}

reaction of interest. A Dunnett means comparison procedure was used to compare the $\mathrm{K}_{\mathrm{PG}}, \mathrm{k}_{\mathrm{PG}}$, and $\mathrm{k}_{\mathrm{PG}} / \mathrm{K}_{\mathrm{PG}}$ values for the whey protein-added reactions to those of the control reaction.

In all of the reactions run in the presence of whey proteins, the $\mathrm{k}_{\mathrm{PG}}$ was significantly higher compared with that of the control. This means that all 3 whey proteins significantly increased the rate of $\mathrm{PG}$ activation compared with the control. Only the $\mathrm{K}_{\mathrm{PG}}$ values for the reactions run in the presence of $\alpha$-LA and $\mathrm{d} \beta$ $\mathrm{LG}$ were significantly different from the control $\mathrm{K}_{\mathrm{PG}}$ value. $\alpha$-Lactalbumin significantly decreased the affinity of uPA for PG, and $\mathrm{d} \beta$-LG significantly increased $\mathrm{uPA}$ affinity compared with that of the control. The $\mathrm{k}_{\mathrm{PG}} /$ $\mathrm{K}_{\mathrm{PG}}$ values calculated for all 3 reactions run in the presence of whey proteins were significantly different from the control. This indicates that both forms of $\alpha$-LA, as well as $\mathrm{d} \beta$-LG, significantly increased the catalytic efficiency of $\mathrm{uPA}$. The $\mathrm{k}_{\mathrm{PG}} / \mathrm{K}_{\mathrm{PG}}$ data support the Lineweaver-Burk plots (Figure 2), which show a downward shift in the plot when whey proteins are added to the reaction. Because of the double reciprocal nature of a Lineweaver-Burk plot, a downward shift is indicative of a stimulatory effect. The kinetic experiments therefore are consistent with the end point PA assay results discussed previously.

In further studies not reported here, the effect of the whey proteins on all 3 kinetic parameters of interest, and particularly their effect on $\mathrm{k}_{\mathrm{PG}}$, was found to be consistent with a 'ping-pong' type of enzyme-catalyzed reaction (Rippel, 2003). In this type of reaction, one substrate interacts with an enzyme, and a product is released. Then, a second substrate binds to the enzyme, which is still bound to the now-modified first substrate, and a second product is released. In this case, the first substrate to bind to uPA is PG, and an oligopeptide is released. The whey protein then binds to the modified PG-uPA complex. The second product released is active PL. The data shown in Table 2 for reactions run in the presence of a whey protein support this type of reaction mechanism. The results indicate that the stimulatory effect of the whey proteins is due to their facilitation of the release of active PL from uPA. In their absence, this release occurs much more slowly, which slows down the overall reaction rate.

\section{Comparison of PL Activity Measured Using S-2251 or SpecPL as the Substrate}

The absorbance at $405 \mathrm{~nm}$ of each of the samples containing a whey protein, corrected for both turbidity measured at $490 \mathrm{~nm}$ and the absorbance of blanks, is compared with the absorbance of a control reaction in Figure 3 . This figure shows that significant $(P<0.0169)$ inhibition of PL activity took place when $\mathrm{d} \alpha$-LA, $\beta$-LG, and $\mathrm{d} \beta$-LG were added to the reaction containing $\mathrm{S}$ 2251 as the substrate; no significant inhibition was seen when SpecPL was used as the substrate. 


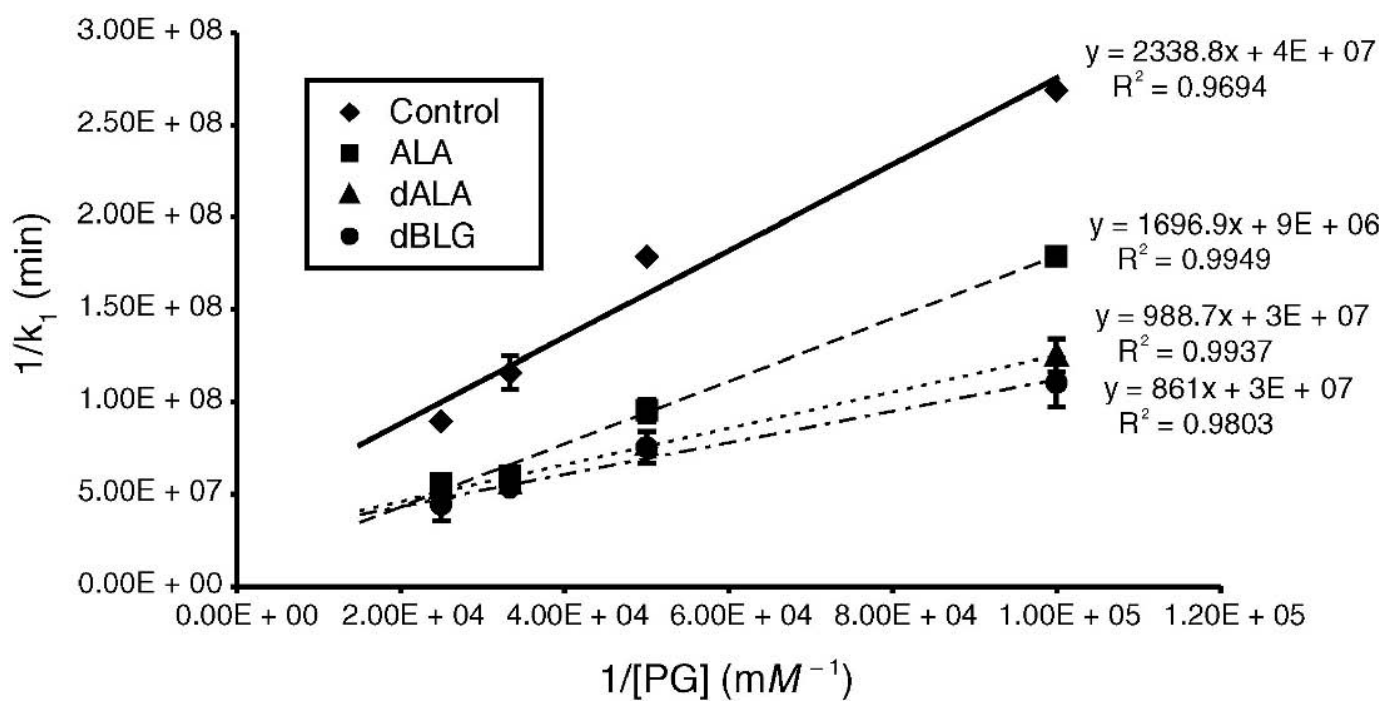

Figure 2. Lineweaver-Burk plots for the 4 coupled reactions of interest. The y-axis is the reciprocal of the plasminogen activation rate $\left(\mathrm{k}_{1}\right)$, and the $\mathrm{x}$-axis is the reciprocal of the plasminogen (PG) concentrations used in the reaction. LA added; $\boldsymbol{\Delta}=0.55 \mathrm{mg} / \mathrm{mL}$ denatured $\alpha$-LA added; $\boldsymbol{\theta}=3.31 \mathrm{mg} / \mathrm{mL}$ denatured $\beta$-LG added. The Michaelis-Menten constant for plasminogen activation $\left(\mathrm{K}_{\mathrm{PG}}\right)$ was determined from the $\mathrm{x}$-intercept of each line, and the rate constant of the reaction ( $\left.\mathrm{k}_{\mathrm{PG}}\right)$ was determined from the $\mathrm{y}$ intercept of each line and the total enzyme concentration used in each reaction. Error bars represent standard errors for each reaction where $\mathrm{n}=3$ in all cases.

The S-2251 inhibition trend with $\mathrm{d} \alpha$-LA, $\beta$-LG, and $\mathrm{d} \beta$-LG seen in Figure 3 supports the findings of Bastian et al. (1993). The data also support the same general trends as those presented by Politis et al. (1993) and some of the results of Hayes et al. (2002), where native and $\mathrm{d} \alpha$-LA and $\mathrm{d} \beta$-LG were found to inhibit PL activity. There were some differences between these results and

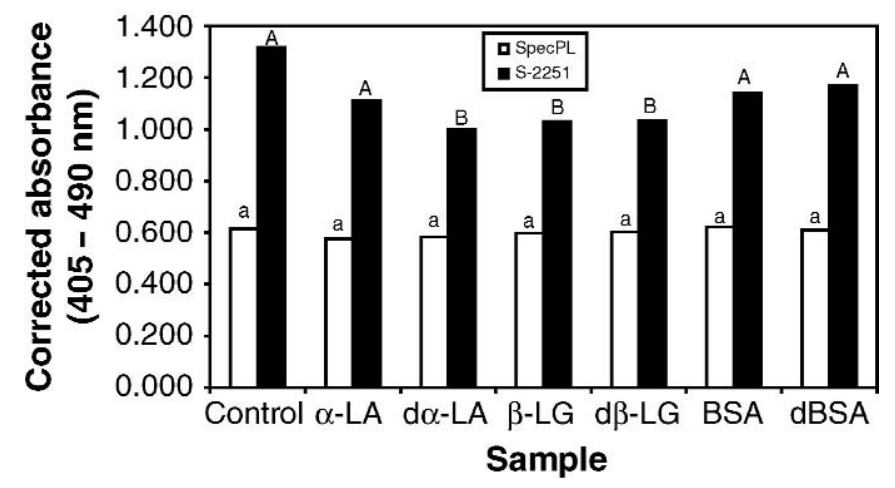

Figure 3. Mean corrected absorbances for samples assayed for plasmin activity. White bars represent reactions where Spectrozyme PL (SpecPL) was used as the substrate; black bars represent reactions where D-Val-Leu-Lys $p$-nitroanilide (S-2251) was used as the substrate. $\mathrm{d} \alpha-\mathrm{LA}=$ denatured $\alpha$-LA, $\mathrm{d} \beta-\mathrm{LG}=$ denatured $\beta$-LG, and dBSA = denatured BSA. Based on the Dunnett procedure, means with different capital letters were significantly different from the control for the S-2251 reaction. Based on the Dunnett procedure, means with the same lowercase letter are not significantly different from the control for the SpecPL reaction. those reported in the literature cited previously, particularly concerning which form of a particular whey protein had a larger effect. However, most of these discrepancies are probably due to different sources of PL, different whey protein concentrations, and different types of assays used to measure effects.

There was no significant difference between the treatments and the control when SpecPL was used as the substrate. The SpecPL results are inconsistent with the results of Bastian et al. (1993), Politis et al. (1993), and Hayes et al. (2002) summarized previously, who all saw inhibition of PL activity by whey proteins.

One of the possible explanations for the differences between the S-2251 results and the SpecPL results may lie in the structure of the 2 substrates themselves. DVal-Leu-Lys $p$-nitroanilide is very hydrophobic (compared with SpecPL), and, especially in the case of $\beta$-LG, could interact with the $\beta$-barrel region of this protein's structure. Similar interactions between this region and small molecules such as retinol have been reported in the literature (Swaisgood, 1996). An interaction would not occur with SpecPL because of an attached sugar group that makes it more hydrophilic. The purpose of the ligand-binding study described hereafter was to test this alternate explanation for the results observed using S-2251.

Ligand-binding results. Figure 4 shows the results of the dialysis experiments performed to determine whether S-2251 could interact directly with $\beta$-LG and 


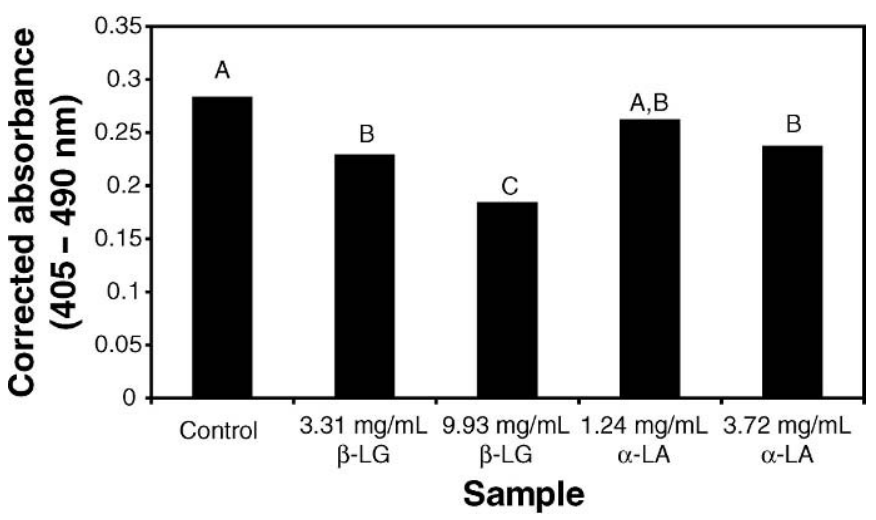

Figure 4. Corrected average absorbance values $(\mathrm{n}=2)$ for the 5 tubes prepared for the equilibrium dialysis experiment. The control contained only D-Val-Leu-Lys $p$-nitroanilide (S-2251) and distilled deionized water. Based on a Tukey-Kramer procedure, means with different letters are significantly different from the control.

$\alpha$-LA. Two observations can be drawn from Figure 4. First, whey proteins interacted with S-2251, which caused less substrate to pass through the dialysis tubing into the dialysate, which resulted in a lower absorbance when the dialysate was assayed. Second, a concentration effect is evident; that is, more whey protein present resulted in more interaction with the substrate. Based on a Tukey-Kramer multiple means comparison procedure, both concentrations of $\beta$-LG were significantly different from the control, as was the higher concentration of $\alpha$-LA.

Taken together, the PL assay results and ligandbinding studies indicate that $\beta$-LG and $\alpha$-LA interact with S-2251, causing S-2251 to be unavailable for reaction with PL. This gives a false impression of inhibition of PL activity by whey proteins and explains the inconsistency between the PL assay results using SpecPL and S-2251. The PL assay results using SpecPL as the substrate show that the stimulatory effects the whey proteins had in the PA end point assay were not due to an effect on the PL produced in the assay.

\section{CONCLUSIONS}

In model systems in which a 2-step assay was used to observe PG activation, whey proteins had significant stimulatory effects on PG activation. Unheated and denatured $\alpha$-LA and $\mathrm{d} \beta$-LG were the most potent stimulators. Kinetic studies of the effect of the whey proteins on PG activation showed significant differences in the kinetic parameters of whey protein-containing reactions that were consistent with the whey proteins facilitating PL release from uPA. Whey protein incorporation into cheese to increase yield might have positive rami- fications for PG activation, and consequently, for reducing cheese aging time. Because of their large stimulatory effects on PG activation, the incorporation of the denatured forms of the major whey proteins, $\alpha$-LA and $\beta$-LG, could have the best potential to reduce cheese aging time. More specifically, because $\beta$-LG is the predominant whey protein, incorporation of its denatured form into cheese could have the most beneficial effect in reducing aging time. It should be emphasized that these potential positive effects could be outweighed by adverse changes to the flavor or texture of the resulting cheese.

Plasmin assay results, coupled with a ligand-binding study, indicated that the effects of the whey proteins in the PA assay were not due to any effects on the PL produced in that assay. However, different synthetic chromogenic substrates used in the PL assay yielded different results when whey proteins were added to the reaction. Some of the model system assays being used currently to investigate the effects of whey proteins on PL activity may be giving inconsistent results. Therefore, care should be taken in choosing synthetic substrates and constructing model system assays. Investigations into systems more representative of reality should be used to confirm model system work.

\section{REFERENCES}

Bastian, E. D., and R. J. Brown. 1996. Plasmin in milk and dairy products: an update. Int. Dairy J. 6:435-457.

Bastian, E. D., K. G. Hansen, and R. J. Brown. 1993. Inhibition of plasmin by $\beta$-lactoglobulin using casein and a synthetic substrate. J. Dairy Sci. 76:3354-3361.

Bylund, G. 1995. Page 23 in Dairy Processing Handbook. Tetra Pak Processing Systems, Lund, Sweden.

Chang, R. 2000. Binding of ligands and metal ions to macromolecules. Pages 318-324 in Physical Chemistry for the Chemical and Biological Sciences. University Science Books, Sausalito, CA.

Grufferty, M. B., and P. F. Fox. 1988. Milk alkaline proteinase. J. Dairy Res. 55:609-630.

Hayes, M. G., P. L. H. McSweeney, and A. L. Kelly. 2002. The influence of native and heat- denatured whey proteins on enzyme activity. 1. Plasmin. Milchswissenschaft 57:208-211.

Nishino, T., T. Yamauchi, M. Horie, T. Nagumo, and H. Suzuki. 2000. Effects of a fucoidan on the activation of plasminogen by uPA and tPA. Thrombosis Res. 99:623-634.

Politis, I., J. H. White, and B. Zavizion. 1995. Whey proteins enhance the rate of plasminogen activation. J. Dairy Sci. 78(Suppl 1):119.

Politis, I., B. Zavizon, D. M. Barbano, and R. C. Gorewit. 1993. Enzymatic assay for the combined determination of plasmin plus plasminogen in milk: Revisited. J. Dairy Sci. 76:1260-1267.

Rippel, K. M. 2003. Plasmin system activity as influenced by whey proteins. M.S. Thesis, Purdue Univ., West Lafayette, IN

SAS. 2001. The SAS System for Windows. Version 8.0, SAS Inst., Inc., Cary, NC.

Singh, H., and A. Waungana. 2001. Influence of heat treatment of milk on cheesemaking properties. Int. Dairy J. 11:543-551.

Swaisgood, H. E. 1996. Characteristics of Milk. Ch.14 in Food Chemistry, 3rd ed. O. Fennema, ed. Marcel Dekker, Inc., New York, NY.

Wohl, R. C., L. Summaria, and K. C. Robbins. 1980. Kinetics of activation of human plasminogen by different activator species at pH 7.4 and $37^{\circ}$ C. J. Biol. Chem. 255:2005-2013. 